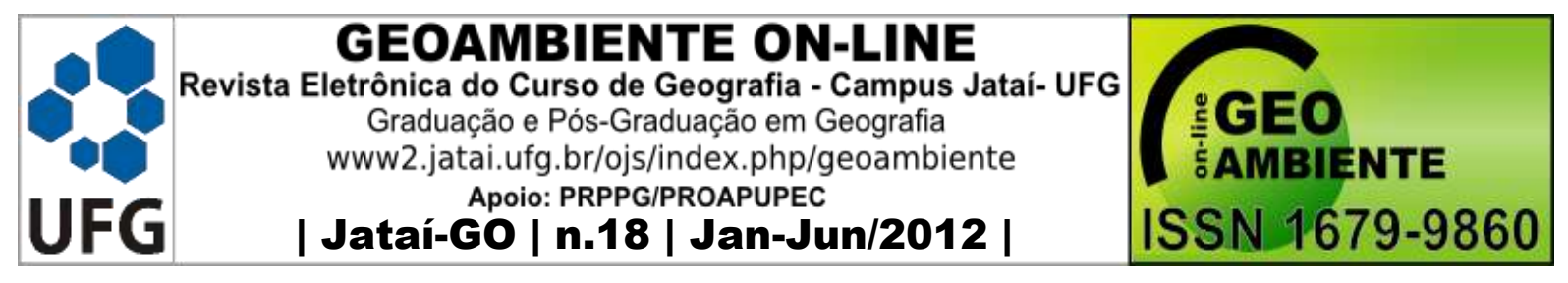

TRANSPORTE URBANO EM DRESDEN (ALEMANHA) E UBERLÂNDIA (BRASIL) - UMA ANÁLISE SOB A PERSPECTIVA DA MOBILIDADE URBANA SUSTENTÁVEL

Sílvio Barbosa da SILVA JÚNIOR ${ }^{\mathbf{1}}$, Cintia Neves GODOI², William Rodrigues

\title{
FERREIRA $^{3}$
}

(1 - Agência Nacional de Transportes Terrestres/ Universidade Federal de Uberlândia, Especialista em Regulação/ Doutorando em Geografia, sbarbosasj@gmail.com, 2 Universidade Federal de Goiás, Doutoranda em Geografia, cngodoi@yahoo.com.br, 3 Universidade Federal de Uberlândia, Professor do Instituto de Geografia, wferreira@ufu.br)

\section{Resumo}

Analisar o transporte público e o espaço urbano no Brasil, especialmente em Uberlândia, e compará-lo com o caso de Dresden na Alemanha se constitui o objetivo deste artigo. Para dar conta dessas relações vamos buscar dados e paisagens de ambas as áreas urbanas, particularmente de suas áreas centrais, para compreender as características de seus sistemas públicos de transporte, analisando as realidades urbanas, para identificar qual é o papel do transporte público nos diferentes casos.

Palavras-chave: Transporte público, Espaço Urbano, Sustentabilidade, Dresden (Alemanha), Uberlândia.

\section{Abstract}

URBAN TRANSPORT IN DRESDEN (GERMANY) AND UBERLÂNDIA (BRAZIL) AN ANALYSIS FROM THE PERSPECTIVE OF SUSTAINABLE URBAN

\section{MOBILITY}

This paper aims to analyze public transportation and the urban space in Brazil, especially in the city of Uberlandia, and compare them to the city of Dresden - Germany. In order to achieve that, we will present data and landscapes of both urban central areas, their public transportation features and analyze the urban reality to identify the public transportation role in each city.

\footnotetext{
Artigo recebido para publicação em 05 de Junho de 2011

Artigo aprovado para publicação em 15 de Fevereiro de 2012
} 


\begin{tabular}{|c|c|c|}
\hline & $\begin{array}{l}\text { GEOAMBIENTE ON-LINE } \\
\text { a Eletrônica do Curso de Geografia - Campus Jatai- UFG } \\
\text { Graduacãá e Pós-Graduação em Geografia } \\
\text { www2.jatai.ufg.br/ojs/index.php/geoambiente } \\
\text { Apoio: PRPPG/PROAPUPEC } \\
\text { | Jataí-GO | n.18 | Jan-Jun/2012 | }\end{array}$ & ISSN $1679-9860$ \\
\hline
\end{tabular}

Keywords: Public Transportation, Urban Space, Sustainability, Dresden (Germany), Uberlândia -MG (Brazil).

\section{Resúmen}

\section{TRANSPORTE URBANO en Dresde (Alemania) y Uberlandia (Brasil) - ANÁLISIS DESDE LA PERSPECTIVA DE LA MOVILIDAD URBANA SOSTENIBLE}

Analizar el transporte público y el espacio urbano en Brasil, en particular en Uberlandia, y compararlo con el caso de Dresde en Alemania constituye el objeto de este artículo. Para dar cuenta de estas relaciones que obtener datos y paisajes de lãs zonas centrales de ambas ciudades, para entender las características de sus sistemas de transporte público, analizar la realidad urbana, para identificar el papel del transporte público en los diferentes casos.

Palabras-clave: Transporte público, Espacio Urbano, Sostenibilidad, Dresde (Alemania), Uberlândia (Brasil).

\section{Introdução}

Falar de transporte e espaço urbano na atualidade exige que este pensamento esteja voltado ao transporte público e à sustentabilidade, ainda mais quando se leva em consideração o dado trazido pelo Fundo de População das Nações Unidas, em 2009, em que metade da população mundial, a partir de 2008, estaria vivendo em áreas urbanas. Trata-se da primeira época da história humana na qual a população urbana alcança os mesmos níveis da população rural, dando indícios de superação. É neste sentido que o pensamento atual deve se voltar a medidas de uso coletivo e sustentável do espaço.

Entretanto, se a cidade é o agente mais profundamente transformador do espaço, talvez o mais degradante, afinal recebe grande parte da humanidade em suas áreas, é ela também que pode abarcar o espaço da transformação, de uma mudança comportamental que permita que as pessoas considerem o futuro em suas ações presentes.

Com base neste pensamento, focamos nossa análise sobre a mobilidade urbana, elemento estruturador da vida urbana contemporânea, discutindo seus principais aspectos, bem como analisando os casos de Dresden, na Alemanha, e Uberlândia, buscando elementos que permitissem que culminássemos com propostas concretas para esta última.

\section{Transporte Público e Espaço Urbano}




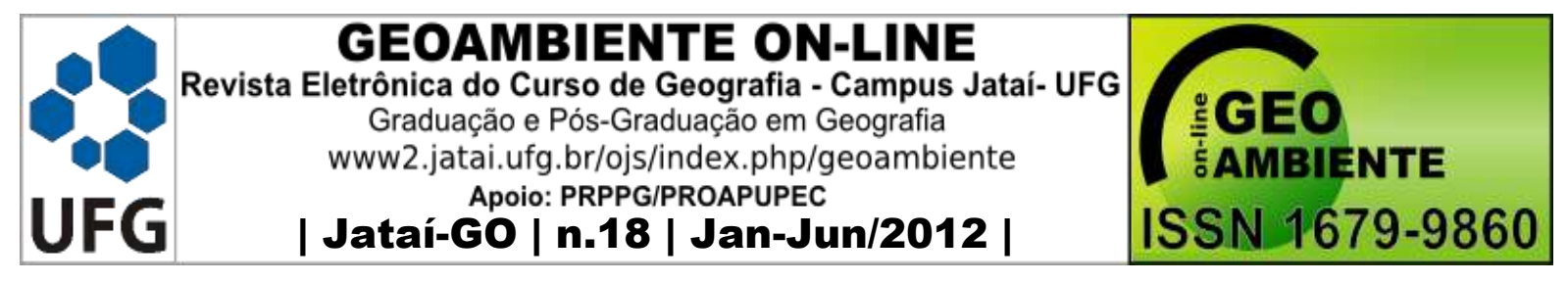

O conceito de sustentabilidade cunhado pelo relatório das Nações Unidas, intitulado Nosso Futuro Comum, estipula justamente um bom futuro como meta das formas de atuar hoje: "atender às nossas necessidades atuais sem comprometer as futuras gerações e dirigir ativamente nosso desenvolvimento em favor da maioria do mundo.”.

Embora polissêmico e largamente discutido, o conceito de sustentabilidade parte do princípio anteriormente citado, mas que queremos reforçar, de que a cidade é o ambiente onde a implementação da "sustentabilidade" pode ser exercitada, ou alcançada, já que é neste espaço que a sociedade está mais densamente presente.

Mas, como pensar a sustentabilidade nas cidades? Há diversos caminhos que podem ser trilhados neste sentido e um deles é o que pretendemos abordar, a difusão do transporte público, o planejamento urbano de maneira a incentivarem a vida, os fluxos, mas buscando ações no espaço com reduzido impacto ambiental.

Assim é preciso pensar a cidade e suas infra-estruturas à luz de alguns princípios relacionados ao conceito de mobilidade urbana sustentável, que nos termos de Oliveira Júnior, define-se como:

[...] a articulação das políticas de transporte e de circulação, integrada com a política de desenvolvimento urbano, com a finalidade de proporcionar o acesso amplo e democrático ao espaço urbano, priorizando os modos de transporte público e o não motorizado, de forma segura, socialmente inclusiva e sustentável. (OLIVEIRA JUNIOR, 2009, p. 02)

Destacam-se, no que se refere à sustentabilidade - em suas esferas ambiental, social, econômica e política -, a necessidade de a rede estar baseada principalmente nos modos coletivos de transporte. Isto devido ao fato de os custos sociais e ambientais dos modos coletivos serem menores que no caso dos modos individuais motorizados.

Como exemplo, vale comparar o espaço físico requerido para transportar o mesmo número de pessoas, em automóveis - geralmente ocupados por 1 ou 2 pessoas - com o espaço ocupado por ônibus transportando a mesma quantidade de passageiros.

Outro item relevante é a atenção aos modos não motorizados para deslocamentos em menores distâncias: os espaços urbanos devem oferecer condições adequadas para que pedestres - com ou sem alguma restrição de mobilidade, e ciclistas tenham condições plenas de se deslocarem pela cidade e acessar as facilidades oferecidas - comércio, serviços, lazer, saúde, educação, trabalho. 


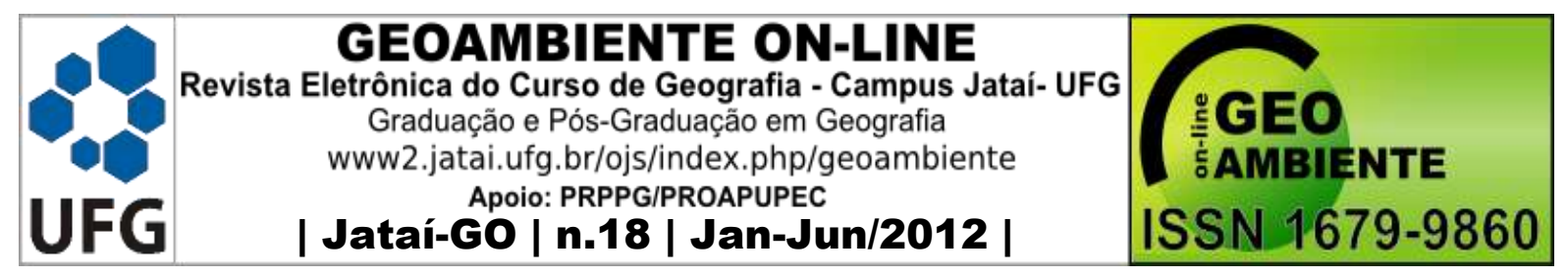

A dificuldade de se deslocar adequadamente a pé pela cidade certamente impacta negativamente no uso do transporte público coletivo, impossibilitando ou dificultando o deslocamento até os pontos de acesso ao transporte coletivo - terminais, pontos de parada e estações. Este é um dos fatores que fortalecem a opção pelos modos individuais motorizados por aqueles que tenham a mínima condição de fazê-lo.

Quando se trata de qualidade dos transportes públicos, outro ponto chave é a necessidade de sintonia entre as características do uso do solo com a rede de transportes. Cabe salientar, em primeiro lugar, a importância do uso misto do solo, ou seja, atividades diversificadas em um mesmo espaço. Trata-se do que aqui denominamos entropia urbana. Entropia é um conceito originário da física e relaciona-se a desordem (RODITI, 2005). No caso de entropia urbana, nos apropriamos deste conceito físico para qualificar a aparente desordem no meio ambiente urbano, traduzindo-se na convivência entre usos do solo diversos em uma mesma zona, em oposição a um zoneamento mais setorizado. Essa aparente desordem de atividades distintas convivendo em um mesmo espaço favorece imensamente os deslocamentos a pé e por bicicleta, tendo em vista que as atividades estarão a uma pequena distância dos locais de trabalho e residência.

Ainda relacionado ao uso do solo, a densidade de ocupação é muito relevante pois, favorece os deslocamentos à pé e não motorizados em geral. Devido à compacidade urbana, menores distâncias são percorridas pelo transporte público e maior carregamento e distribuição mais uniforme da demanda, proporcionando menores custos e maior eficiência para os sistemas coletivos.

A noção de compacidade urbana e as associadas melhorias para o transporte público não é uma constante, pois em cidades muito populosas e adensadas, um acréscimo de densidade em determinadas zonas pode não significar um auxílio na organização dos sistemas de transporte público. Obviamente não negligenciamos os efeitos de um adensamento excessivo e que passa a provocar deseconomias de escala. Porém, a questão das deseconomias não se aplica ao nosso estudo de caso, pois analisamos possibilidades para cidades com população da ordem de 500-600 mil habitantes.

Segundo Rogers (2008),

[...] devemos investir na ideia de "cidade compacta" - uma cidade densa e socialmente diversificada onde as atividades econômicas e sociais se sobreponham e onde as comunidades sejam concentradas em torno das unidades de vizinhança. Este 


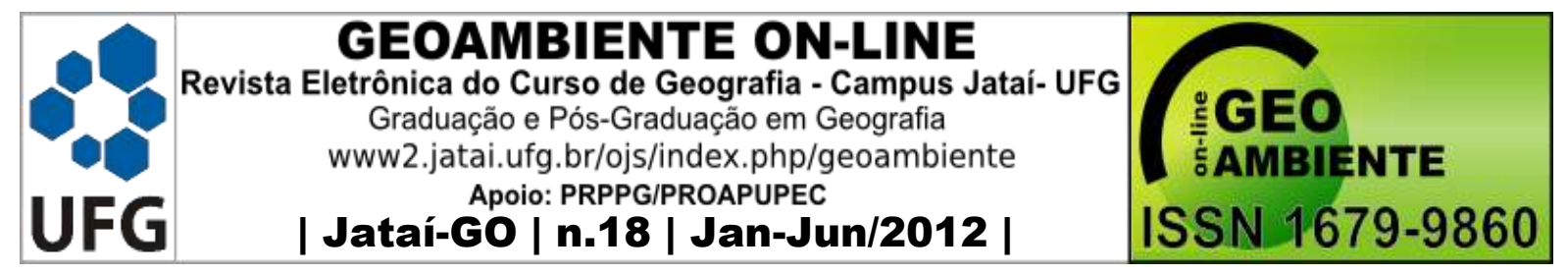

conceito difere radicalmente do atual modelo urbano dominante, aquele dos Estados Unidos: uma cidade dividida em zonas por funções, com áreas de escritórios centrais, shopping centers e áreas de lazer fora da cidade, bairros residenciais distantes e vias expressas. (Rogers, 2008, p. 33)

Com um uso menos entrópico, as pessoas tendem a se deslocar mais no espaço para acessar os serviços ofertados pela cidade. A baixa densidade, por sua vez, faz com que os deslocamentos sejam, em média, maiores do que no caso de uma área urbana mais densa. Neste cenário, o transporte público percorre maiores distâncias para atender às linhas de desejo dos usuários, sendo, portanto, mais caro e mais demorado que numa região mais adensada.

Com uma maior necessidade de deslocamentos, associada à menor eficiência dos transportes públicos e às dificuldades de deslocamento não-motorizado, a tendência é que o peso do transporte individual motorizado na matriz de transportes seja grande.

Um peso maior do transporte individual, por sua vez, associa-se a uma série de problemas socioambientais: a poluição sonora, visual e do ar, a fragmentação do espaço pelas vias de trânsito rápido, os congestionamentos - traduzidos em perda de horas no trânsito -, o consumo maior de espaço para transportar pessoas, a falta de estacionamento, os acidentes de trânsito e o aumento dos tempos de viagem, inclusive para os usuários de transporte coletivo.

De acordo com Rogers (2008) à medida que o transporte individual torna-se parte integral do planejamento urbano, as esquinas, as formas e superfícies dos espaços públicos são todos determinados em prol do motorista. E, isto transforma radicalmente o espaço urbano fazendo com que as cidades, originalmente criadas para celebrar o que temos em comum, unir, passem a ser fragmentadas, projetadas para manter-nos afastados uns dos outros.

Mas, este modelo fragmentador está em crise, pois é dispendioso e insustentável do ponto de vista das políticas ambientais. Os gastos são maiores, as pessoas estão insatisfeitas, os ambientes insalubres, os gastos com saúde pública aumentaram, doenças respiratórias, doenças psicológicas, depressão, estresse dentre outros problemas estão atrelados à má qualidade do ambiente urbano. E, tudo isso exige novas alternativas para as cidades.

Alguns desenhos já foram esboçados neste sentido, um deles é o investimento nos transportes coletivos e em desenhos urbanos mais coesos e multifuncionais.

A necessidade de se pensar em um sistema ou modelo de transporte público mais econômico, ecológico e saudável também vem reforçar um pensamento na sociedade 


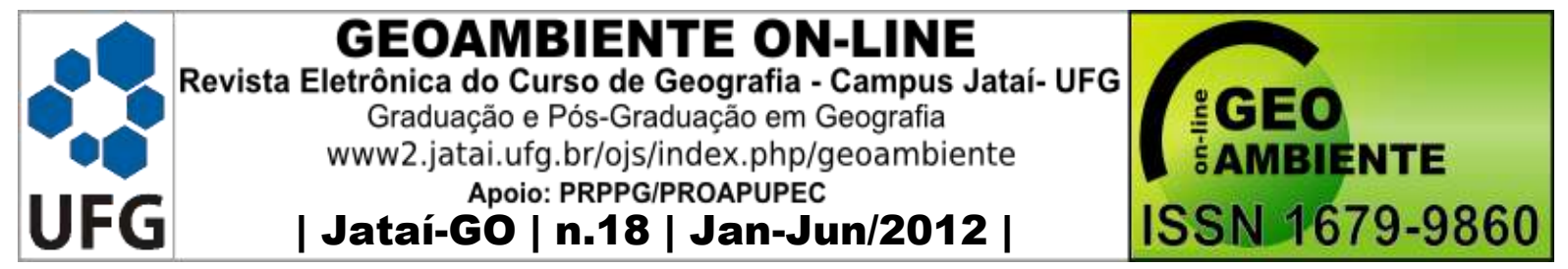

vindoura. Sabemos que está em vigor um processo de envelhecimento da população, ou seja há um declínio da fecundidade na Europa e no Brasil e este declínio resulta numa inversão da pirâmide demográfica que se processa com o aumento do número de pessoas com idade avançada e uma diminuição de nascimentos.

E, o envelhecimento da população como um processo de difícil retorno exige um planejamento para esta nova característica de nossa sociedade já que uma população mais idosa requer mais infra-estrutura em alguns setores.

\footnotetext{
Durante los últimos cincuenta años, la esperanza media de vida em todo el mundo há aumentado de 46 a 64 años, y la diferencia entre la longevidad media de los habitantes de los países desarrollados y la de los países em vias de desarollo há disminuido de los 26 a los 12 años. Cuanto más vivimos, más consumiimos, y a edades avan'zadas se incrementa nuestra dependência de la calefacción, la iluminación y el transporte. (Edwards, 2005, p. 33)
}

Assim, torna-se imprescindível pensar em transportes públicos e coletivos buscando incrementar qualidade de vida e voltar os esforços especialmente para os transportes de superfície (ônibus, bondes), em função de seus comprovados ganhos sociais. Para tanto é preciso diversas ações como a delimitação de faixas segregadas, vias exclusivas, inserção de novos veículos que diminuam ou mesmo anulem a influência do tráfego geral no fluxo do modo coletivo.

Há, ainda, a necessidade que as diversas instituições envolvidas com o planejamento de transportes se articulem adequadamente. A falta de integração do transporte e de articulação entre os órgãos denunciam a falta de capacidade desses órgãos em cumprir sua missão de oferecer uma mobilidade urbana e um meio urbano mais humano. Associa-se a isto a total carência de informações ao usuário, bem como a disponibilização de canais de comunicação com este usuário, diminuindo as possibilidades de participação popular nas decisões dos órgãos, contribuindo para a perpetuação da situação atual. Isto choca totalmente com o que ocorre em locais onde a população participa de forma mais ativa e constante, como destaca Caiafa, 2007, no caso de Nova Iorque.

A autora (CAIAFA, 2007) destaca principalmente o papel do relacionamento dos prestadores de serviços de transportes com os usuários. A maior presença dos usuários nas decisões de transporte, bem como a tradição construída de um relacionamento mais próximo 


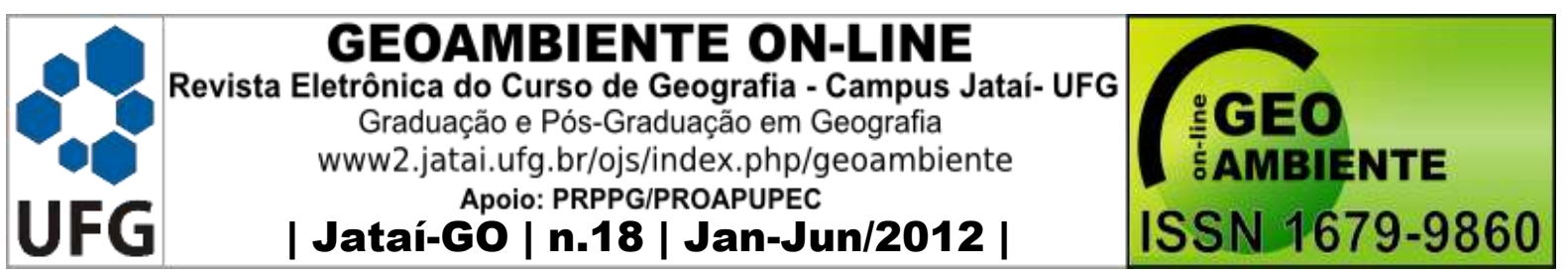

entre usuários e prestadores, favoreceram um serviço de melhor qualidade e o desenvolvimento das atividades urbanas ao redor das redes de transportes públicos.

Buscando analisar exemplos que possam contribuir para pensar nossos modelos de transporte coletivo no Brasil analisaremos, a seguir, o caso de Dresden, na Alemanha, e de Uberlândia, MG, no Brasil. Estes foram escolhidos por serem municípios, ou cidades, de porte similar e em ambientes muito distintos, o que nos permite enxergar práticas e tentativas relacionadas a espaços diversos.

\section{3. $O$ caso de Dresden}

Dresden é a capital do estado alemão da Saxônia (Mapa 1) e possui aproximadamente 500 mil habitantes. Conjuntamente com Leipzig, no mesmo estado, e Berlim, a capital federal alemã, é um dos principais centros da porção leste daquele país (Mapa 2).

Mapa 1: Localização de Dresden na Alemanha e na Europa

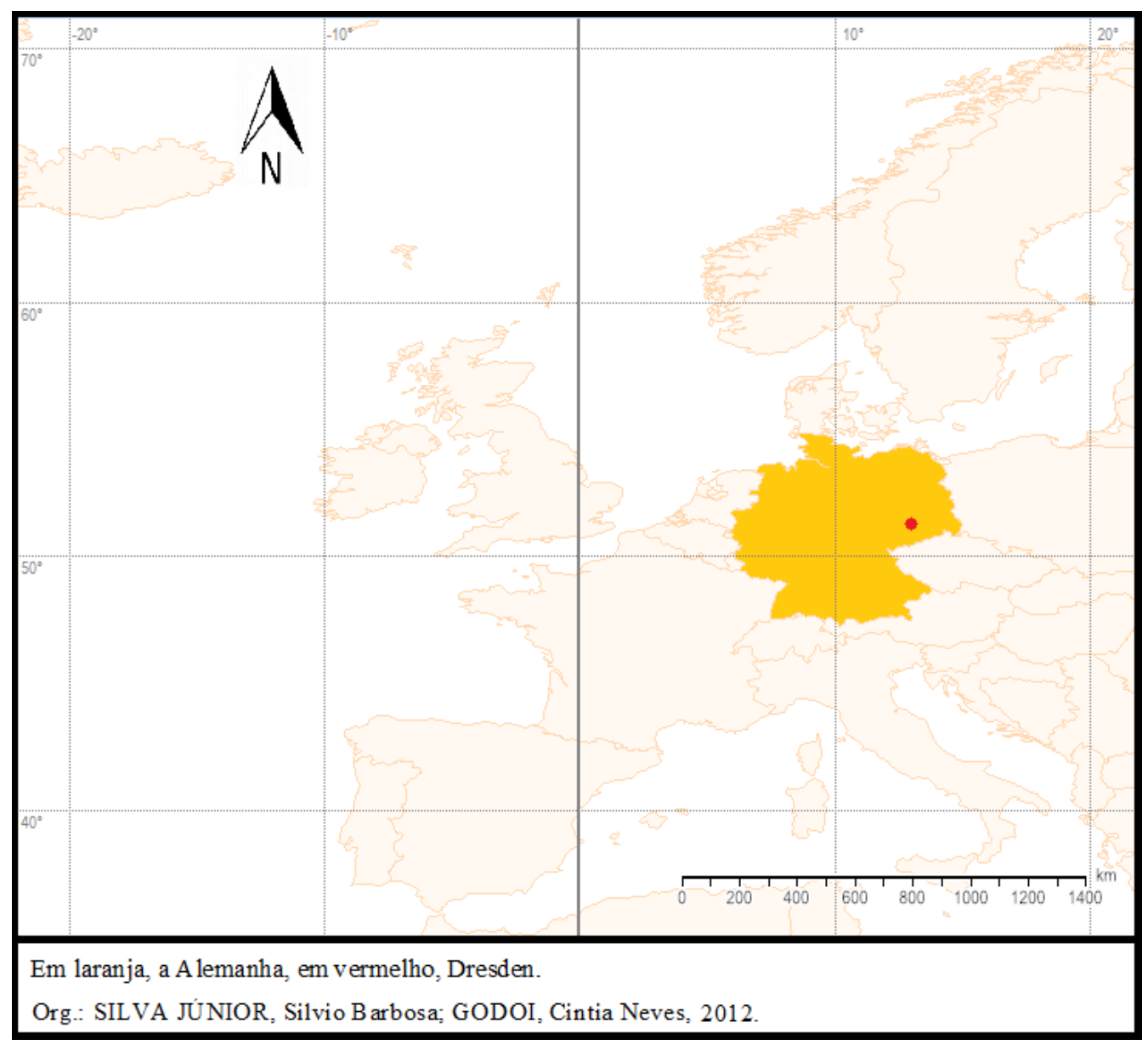




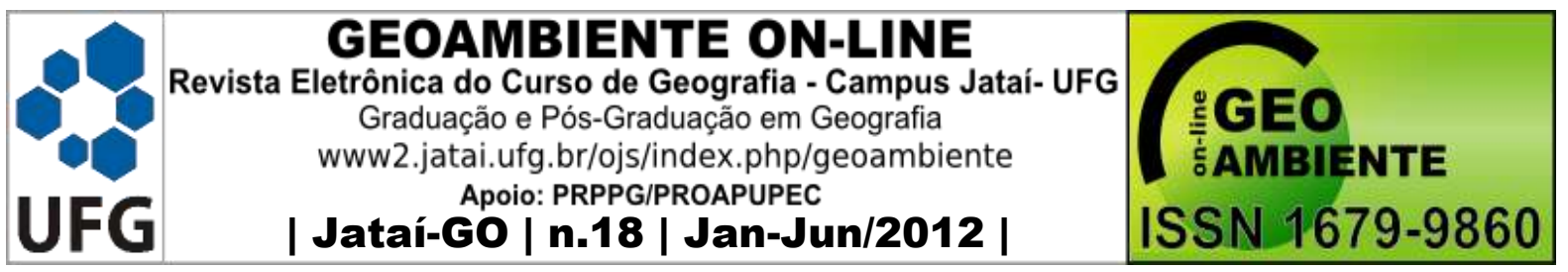

Mapa 2: Esquema da Rede de Transportes de Dresden. Linhas de trem e Bondes.

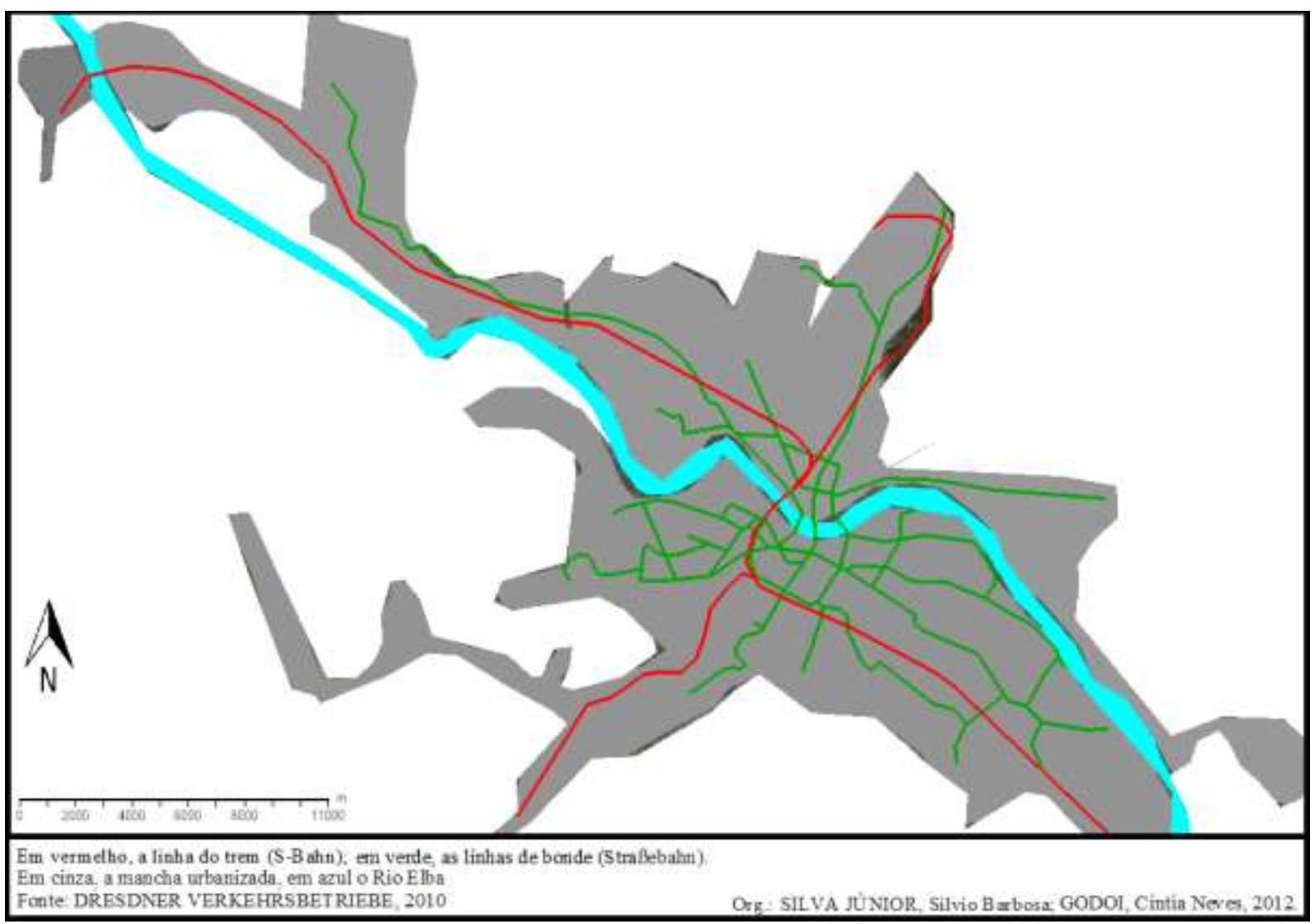

O sistema de transporte público de Dresden é baseado em quatro modos distintos: os trens regionais e suburbanos, que ligam Dresden aos povoados e cidades mais próximos, operados na faixa de domínio das ferrovias da Deutsch Bahn; os ônibus urbanos; os ferryboats que navegam no Rio Elba e o sistema de bondes. Este último configura-se como a espinha dorsal do sistema de transportes local.

Estes sistemas possuem um tipo de integração, gerida por uma autoridade regional, a Dresdner Verkehrsbetriebe. A integração é total, e pode se trocar de modo à medida em que isso se faz necessário, possibilitando múltiplas combinações para os usuários. A mancha urbana de Dresden, bem como sua região adjacente, é dividida em zonas tarifárias e que, conforme a origem e o destino, tem-se tarifas diferenciadas.

As linhas de trens suburbanos e regionais é sobreposta aos trechos onde as ferrovias nacionais adentram a área urbana, interligando as estações onde os trens de longo curso passam, bem como outras implantadas exclusivamente para os trens locais/ regionais. Uma das linhas atinge, ainda, o aeroporto local. É notório que nas principais cidades alemãs os 


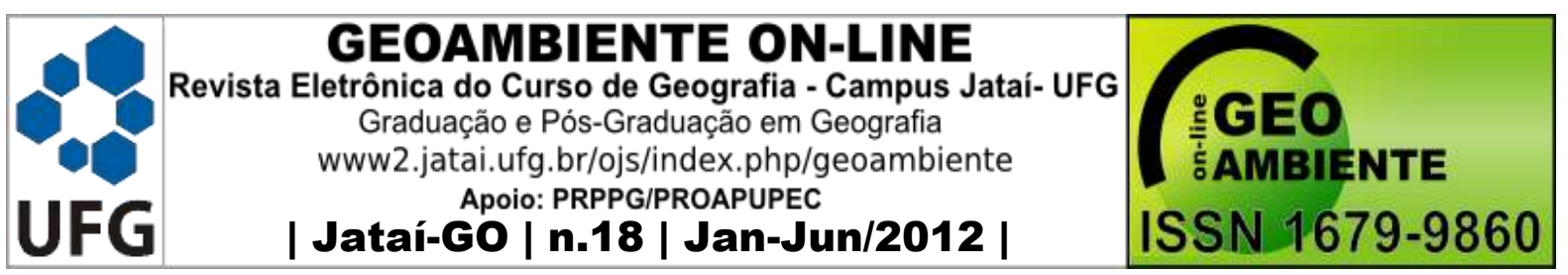

centros urbanos são ligados por via férrea - seja metrô, sejam trens suburbanos ou linhas de bonde.

As linhas de bonde - lá chamadas de straßebahn, em alemão "trem de rua" constituem o essencial do sistema. É constituído por 12 linhas diametrais, que se cruzam principalmente em alguns pontos no centro da cidade, embora haja trechos comuns entre mais de uma linha, possibilitando troca de itinerário sem necessidade de se passar na área central. A opção pelos bondes guarda relação com três características: a leveza dos seus veículos, a boa capacidade dos veículos e a ausência de poluição atmosférica ao longo da linha.

Os bondes atendem a demanda principal, que se concentra uso lindeiro mais denso ao longo de seus eixos. São complementados pelas 28 linhas de ônibus que, em algumas áreas, compartilham espaço com os bondes (Fotografia 1).

Fotografia 1: Estação compartilhada entre bonde e ônibus. Dresden, 2010.

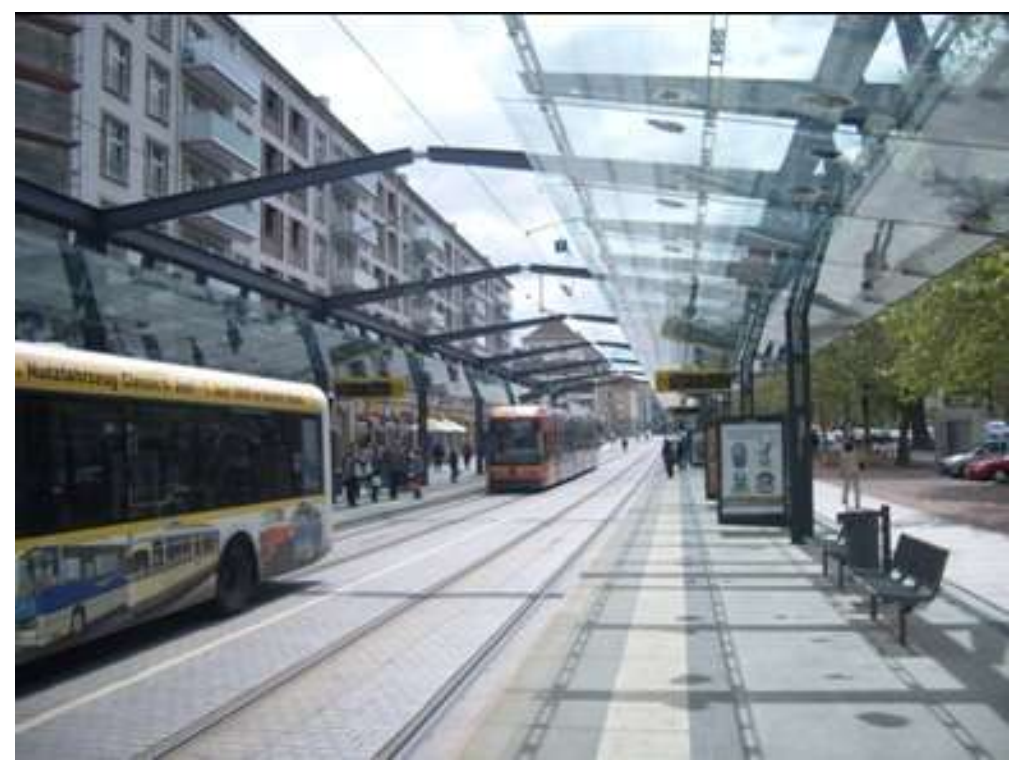

Autor: Silva Junior, 2010.

Fonte: Arquivo pessoal.

No caso de Dresden, existe pouca segregação do tráfego de bondes em relação aos demais veículos. A segregação é mais intensa nas áreas centrais, onde se cruzam e acumulam várias linhas, possuindo maior intensidade de tráfego, e em vias nas quais a largura permite. Em boa parcela das vias, o tráfego de bondes segue em meio aos carros. No entanto, há de se destacar, o tráfego de veículos particulares na cidade de Dresden é menor que numa cidade brasileira de mesmo porte, como Uberlândia, por exemplo. 


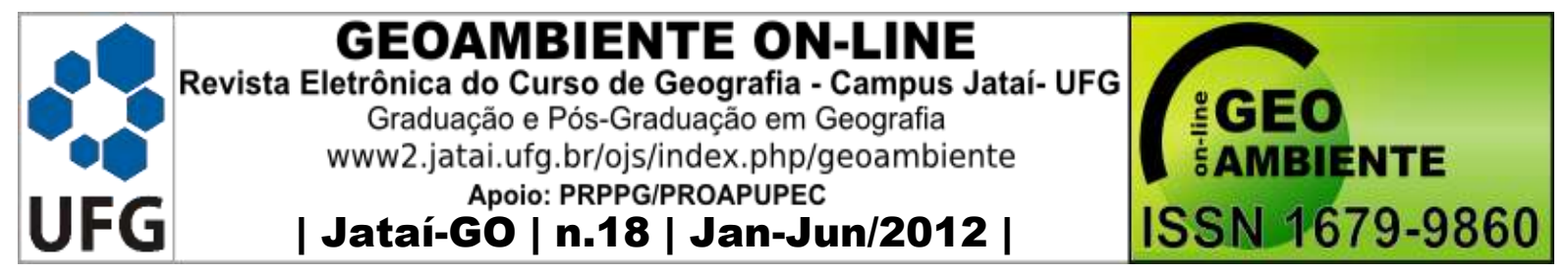

Isto merece uma reflexão dupla: a tradição em usar o transporte público como prioritário estimula investimentos que incrementem sua qualidade. Deste modo, são tomadas medidas restritivas ao uso do automóvel enquanto se implantam facilidades ao tráfego dos transportes coletivos e, ainda, dos não motorizados, com amplas áreas destinadas aos pedestres e ciclistas. Os transportes públicos apresentam, então, grandes demandas - nos sistemas de bondes, ônibus e ferry-boats são transportados, diariamente, 400 mil pessoas (DRESDNER VERKEHRSBETRIEBE, 2010) Deste modo, as vias não apresentam tráfego que justifique a necessidade de segregação na totalidade das áreas. Sem segregação, com a convivência do tráfego, a prioridade é do transporte público.

Outro ponto que chama atenção é a questão da confiabilidade. Os veículos passam pelas paradas sem atrasos. Há ampla disponibilidade de informação: em todas as paradas existe um painel com um mapa da rede, regras tarifárias e horários. Em uma localidade sujeita a temperaturas muito baixas, a confiabilidade é extremamente necessária para que o usuário se exponha o mínimo possível a condições adversas. É dos fatores que contribuem para o uso extremamente disseminado do uso do transporte público.

As paradas são, em sua maioria, bastante simples, possuindo apenas a identificação com nome e painel de informações. Em boa parte existe, ainda, painel eletrônico que informa o tempo restante para que a próxima composição passe. Nas estações mais centrais e, consequentemente mais movimentadas, existe um mobiliário urbano de melhor qualidade, com bancos, proteção contra intempéries e maior qualidade arquitetônica.

\section{O Caso de Uberlândia}

Uberlândia é um município habitado por 634.345 habitantes, segundo estimativas do IBGE em 2009, localizado na mesorregião do Triângulo Mineiro e Alto Paranaíba, no extremo oeste do estado de Minas Gerais (Mapa 3), Brasil. É importante destacar que Uberlândia teve um rápido crescimento populacional e ascendeu na hierarquia urbana regional especialmente a partir da década de 1970.

Segundo o IBGE (2009) este município possui uma frota de mais de 199.066 veículos, dos quais aproximadamente 130 mil automóveis e pouco mais de 12 mil ônibus, dos quais a frota de ônibus urbanos é de 395 ônibus. Hoje, o sistema local de transportes transporta aproximadamente 170 mil passageiros por dia (Prefeitura Municipal de Uberlândia, 2009). 


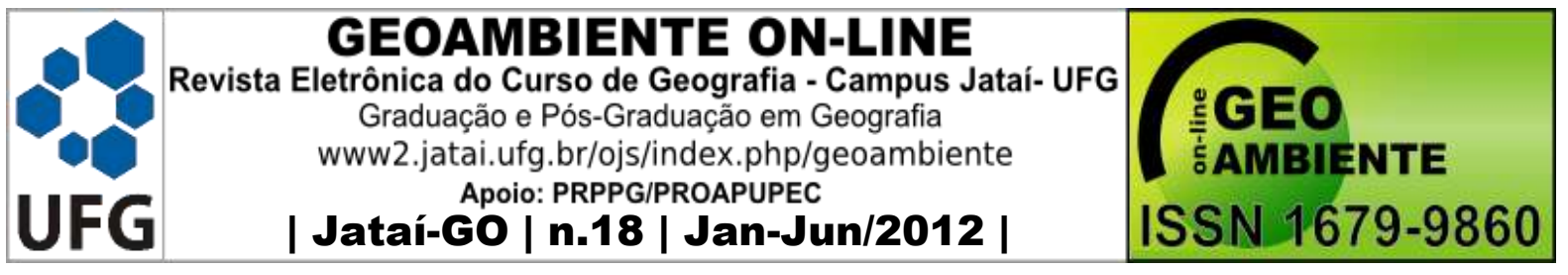

Mapa 03: Localização de Uberlândia, MG.

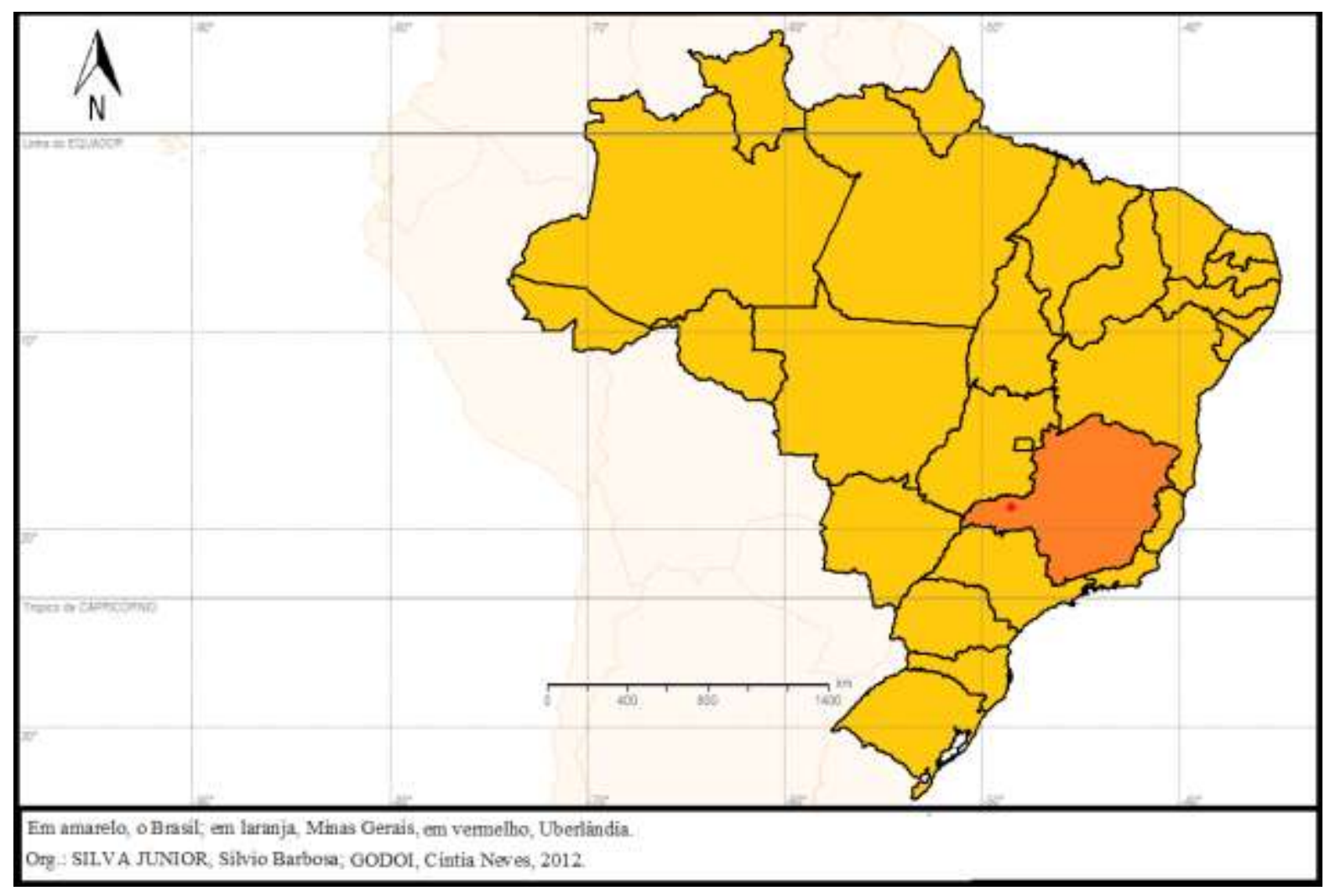

O sistema de transportes funcionando atualmente em Uberlândia - SIT (Sistema Integrado de Transporte) - foi implantado na década de 1990, no ano de 1997, baseado no sistema em operação em Curitiba. Trata-se de um sistema tronco-alimentado, operado por ônibus. As linhas troncais ligam quatro terminais periféricos e bairros densos ao Terminal Central, localizado no centro da cidade. Os terminais são alimentados por linhas que vêm dos bairros e os terminais periféricos são interligados, entre si, por linhas interbairros, que não passam pela área central.

Quanto ao aspecto tarifário, o SIT permite que os usuários possam se deslocar para qualquer ponto da cidade pagando apenas uma tarifa e mudando de ônibus nos terminais quantas vezes forem necessárias.

Os eixos principais de transporte (Mapa 4), servidos pelas linhas troncais, coincidem com aqueles definidos no Plano Diretor municipal que vigeu entre 1994 e 2006 como eixos estruturais. Tais eixos deveriam receber um adensamento maior e maior diversidade de serviços, visando uma expansão linear das atividades típicas de áreas centrais, baseado na maior oferta de transporte ao longo do eixo. 


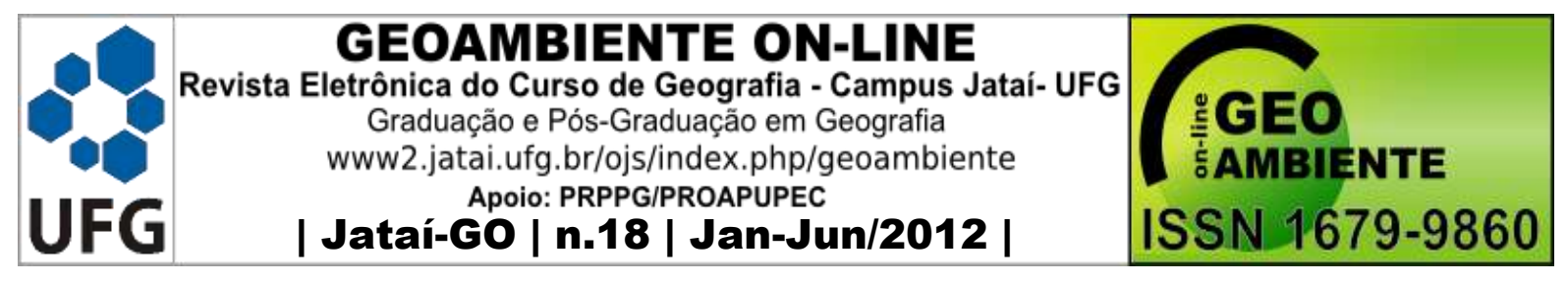

Mapa 4: Eixos Estruturais no Plano Diretor de Uberlândia-MG, 1994.

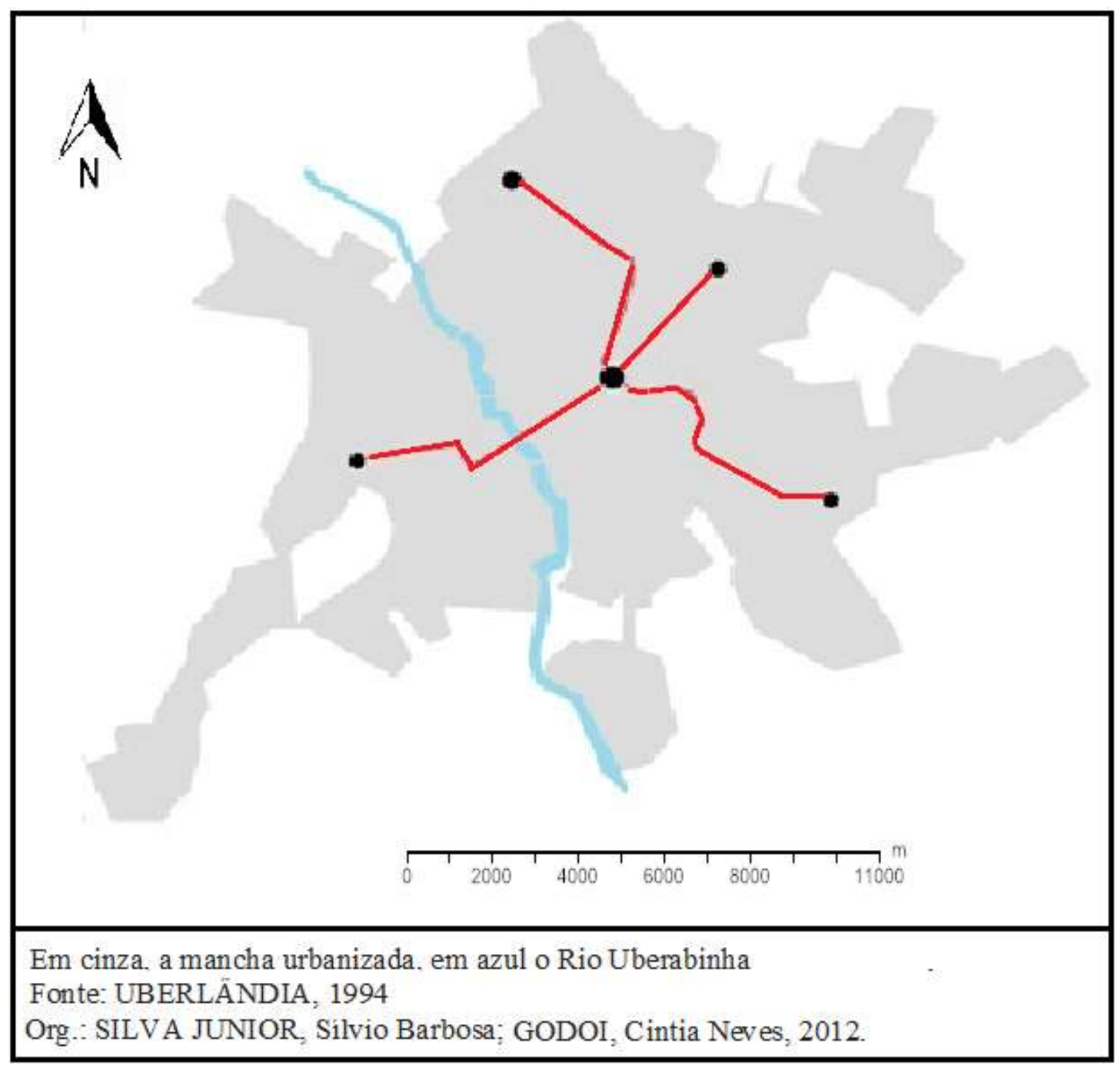

Como consequência deste novo modelo, esperava-se uma desconcentração de veículos no centro da cidade, liberando áreas para intervenções que tornassem o ambiente daquela área mais agradável aos pedestres. No entanto, a implantação de muitas linhas diretas ao centro comprometeu este aspecto, fazendo com que a redução do número de ônibus na área central não fosse tão intensa quanto esperada, assim como sobrecarregando o Terminal Central.

Uma intervenção de grande impacto, desde então, foi a implantação do corredor de ônibus (Fotografia 2) da Avenida João Naves de Ávila, em 2006, contemplando uma faixa 


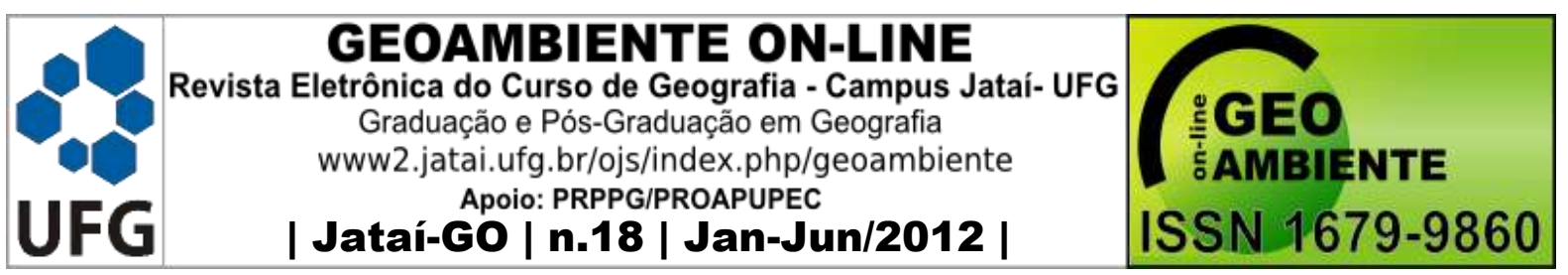

exclusiva por sentido junto ao canteiro central da avenida e 13 estações de embarque, permitindo que o usuário pague a tarifa antecipadamente, acelerando o processo de embarque.

Fotografia 2: Estação no corredor de ônibus da Avenida João Naves de Ávila. Uberlândia, 2007.

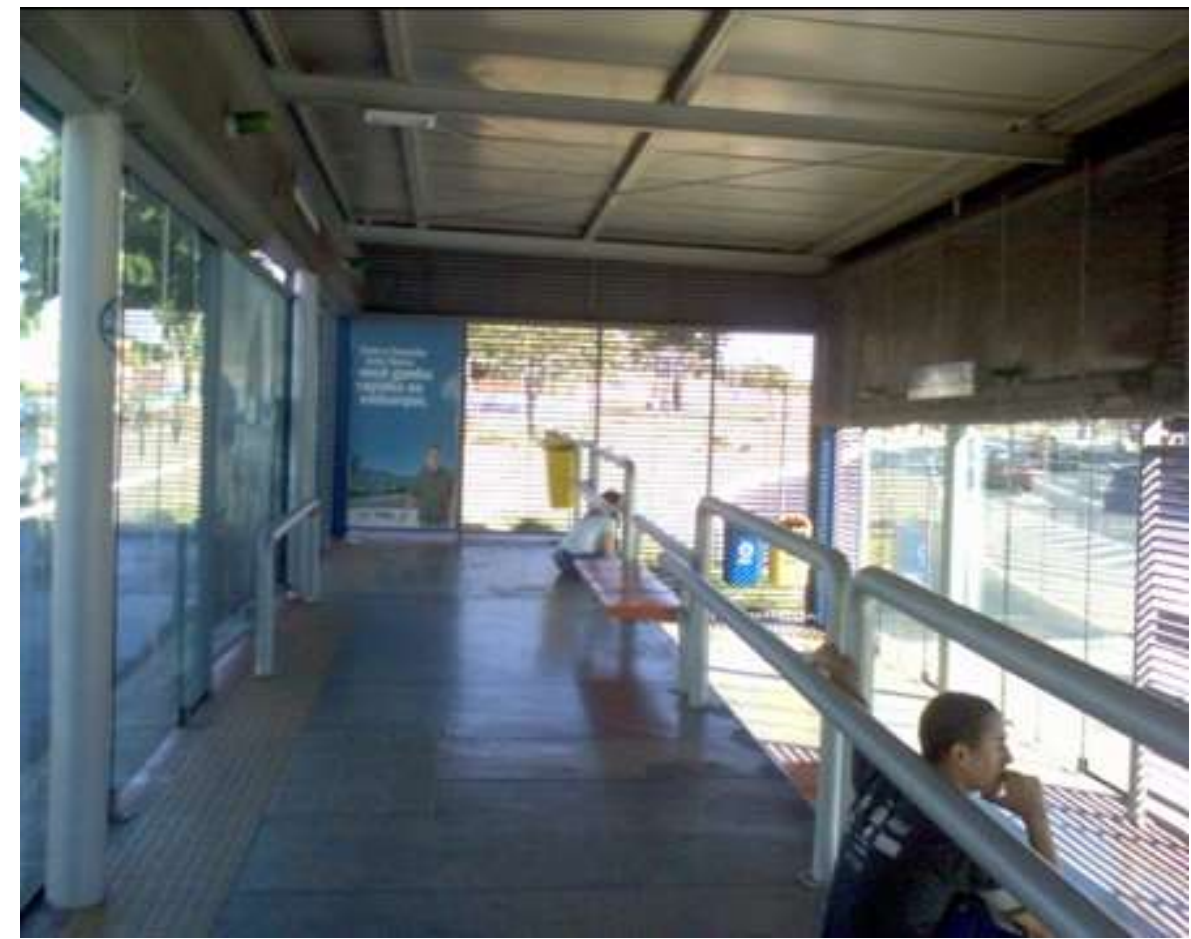

Autor: Silva Junior, 2010.

Fonte: Arquivo pessoal.

Na revisão do Plano Diretor, em 2006, foram propostos mais quatro terminais de integração (Mapa 05) servindo a mais quatro eixos, bem como dois anéis ao redor da área central, um mais externo, ligando os terminais de ponta, e um a meia distância entre o terminal central e os periféricos, possibilitando uma integração sem necessidade de passar pelo centro ou pelos terminais periféricos.

Prevê-se, ainda, a adequação das vias por onde passam os eixos principais, implantando faixas exclusivas/ corredores nos mesmos moldes do executado na Avenida João Naves de Ávila. Isto, caso seja executado, melhorará o desempenho dos veículos, permitindo o desenvolvimento de maiores velocidades e, ainda, tendo como consequência uma maior confiabilidade do transporte público como um todo. 


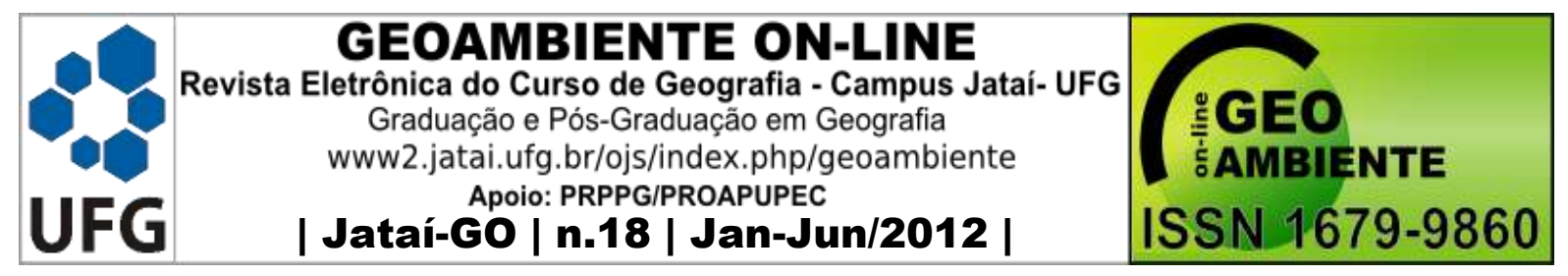

Mapa 05: Eixos Estruturais, anéis e terminais no Plano Diretor de Uberlândia-MG, 2006.

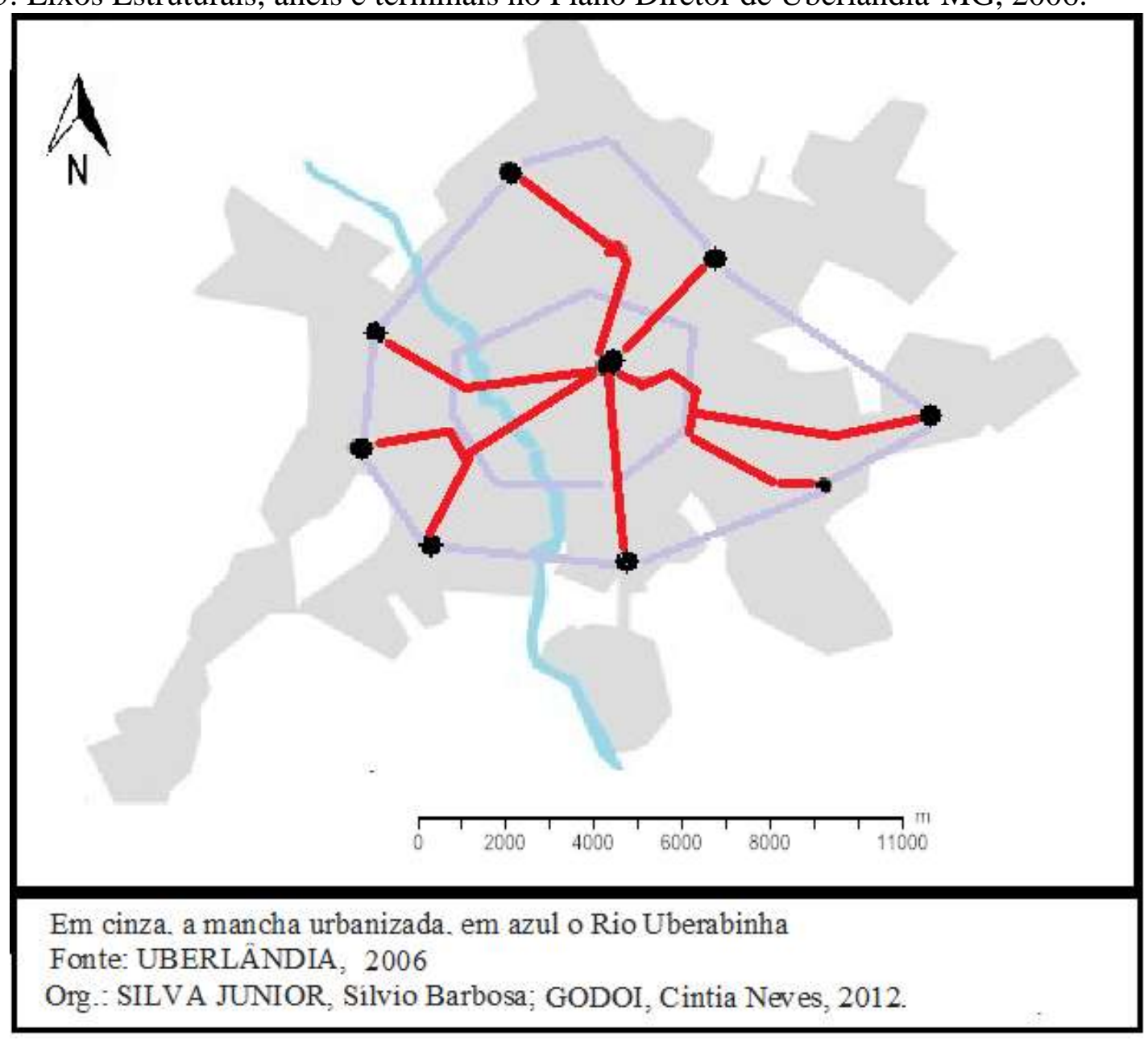

\section{Pensando Uberlândia sob o modelo de Dresden}

Qualquer análise atual da lógica dos sistemas de mobilidade de Uberlândia ou de qualquer município no Brasil passa pelo questionamento do modelo automobilístico escolhido pelas cidades como já dissemos anteriormente.

Uberlândia não é diferente da maioria das cidades brasileiras, há uma opção visível pelo transporte individual e as demais formas de transporte costumam ser pensadas como complementares aos automóveis. Ou seja, não há medidas mais radicais que optem pelo transporte público e pela ciclovia, embora haja medidas sem grandes impactos.

Este modelo se torna insustentável em longo prazo. Se todos nós dispusermos e utilizarmos apenas automóveis o trânsito, a qualidade de vida, do ar, sonora, dentre outras, comprometerão a sanidade das cidades. 


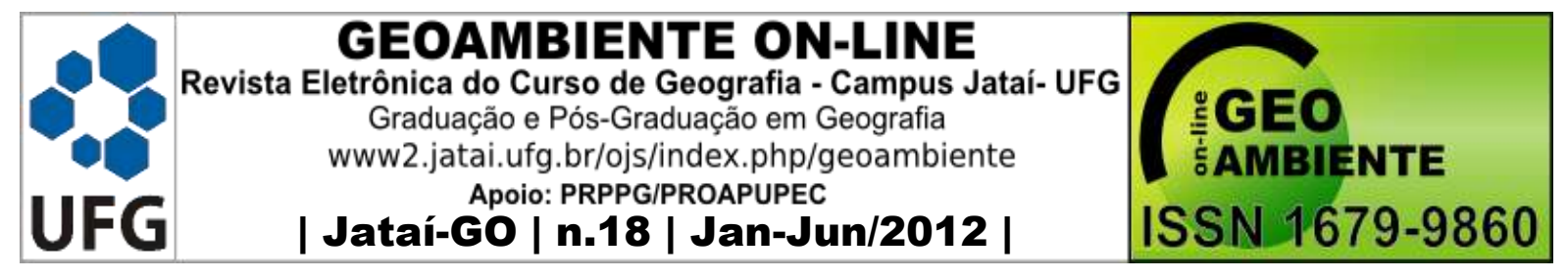

Cabe lembrar que buscamos, com base no exemplo de Dresden, pensar um planejamento de transporte que pudesse priorizar o uso coletivo do espaço, que diminuísse o volume e os impactos do automóvel nas vias, que ampliasse a circulação de pedestres e ciclistas visando um modelo menos poluente, menos dispendioso de combustíveis fósseis e, portanto mais sustentável.

O primeiro item a considerar é a substituição de ônibus por veículos elétricos sobre trilhos. Os VLT (Veículo Leve sobre Trilhos) ou bondes, de tração elétrica. Esta opção se dá, primeiramente por causa da tração elétrica; sendo elétrica, não existe emissão gasosa ao longo dos eixos, melhorando a qualidade ambiental nestes lugares.

Por ser um transporte sobre trilhos, oferece menor flexibilidade de alteração de rotas, muito comum em linhas de ônibus. O que pode, inicialmente, parecer uma desvantagem, aqui tomamos como uma vantagem: com a necessidade de implantação de novos trilhos para alterar a rota, tais alterações seriam bem menos comuns do que no caso dos ônibus, possibilitando uma melhor sinergia entre o eixo principal e o uso do solo mais denso, fixando a demanda principal no local onde existe maior oferta.

Com base nos eixos estruturais vigentes no Plano Diretor atual, bem como os anéis de integração; considerando, ainda, áreas de grande demanda, elaboramos a seguinte proposta de rede no mapa 6.

Comumente se associa o uso de bondes em áreas de uso mais denso, atendendo a médias e grandes demandas. Associa-se, ainda, a grandes custos de implantação, devido à necessidade de desapropriações e segregação da via. A experiência de Dresden mostra que isto não é a verdade absoluta. As linhas não são totalmente segregadas do fluxo de veículos, exceto na área central e áreas de maior demanda.

Uberlândia possui vias largas e, notadamente nos grandes eixos, não necessitaria de desapropriações de grande monta. Com pequenos ajustes seria possível implantar o sistema utilizando uma faixa de tráfego ou estacionamento.

Um aspecto problemático em Uberlândia e em diversas outras cidades do país e do mundo, é o uso do centro da cidade. No caso de Uberlândia, como de vários outras, o centro corresponde à área onde a cidade começou, com suas praças centrais tomadas por comércios e construções antigas convivendo com construções mais contemporâneas.

Pensar um uso mais sustentável para o centro é justamente manter sua fluidez, mas concentrando apenas pedestres, transporte coletivo e ciclistas. Para nós é de suma importância 


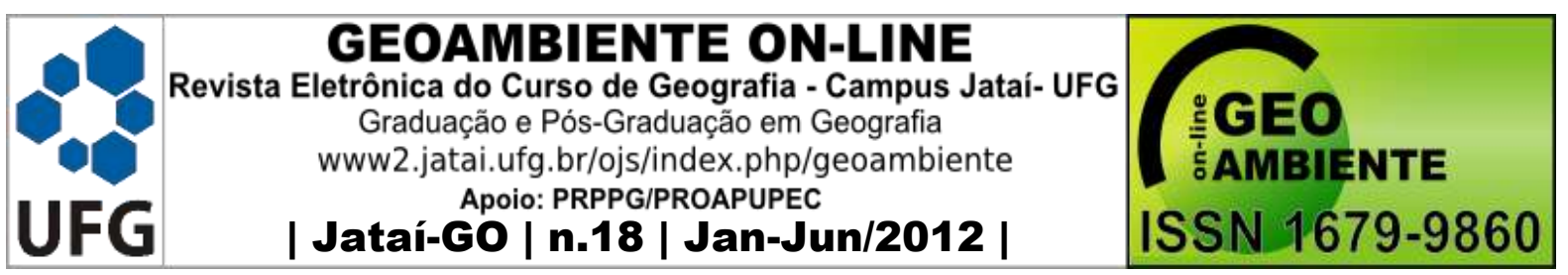

a diminuição do uso de automóveis particulares nas áreas centrais, pois o conflito entre pedestres, ciclistas, automóveis particulares e coletivos implicam uma paisagem e ambiente problemáticos.

Mapa 06: Proposta de Rede de Transporte para Uberlândia - SILVA JÚNIOR e GODOI, 2012.

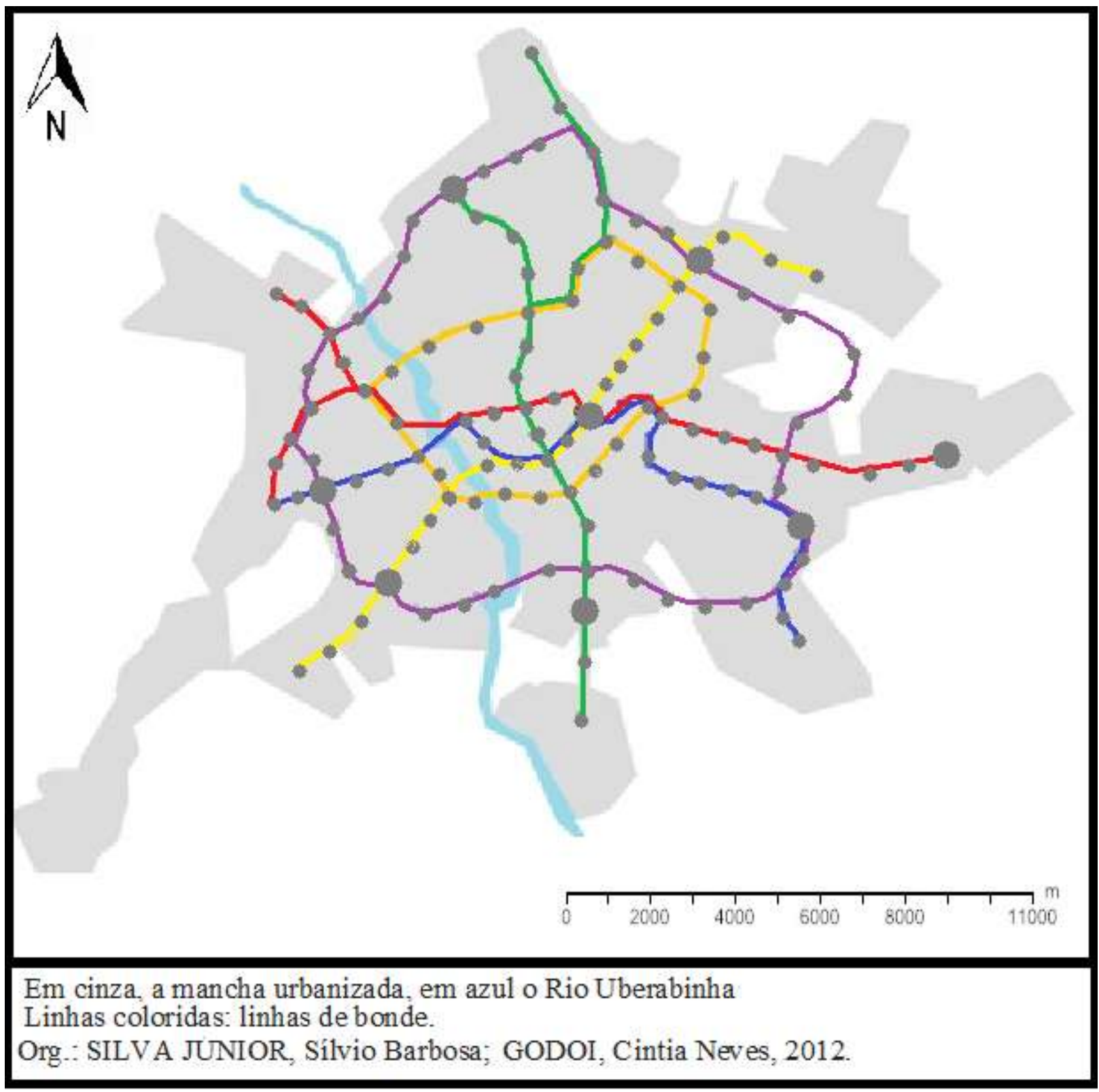

Segundo Rogers (2008) foram feitas pesquisas em São Francisco, nos Estados Unidos, comparando ruas situadas em diferentes bairros para avaliar o impacto do tráfego na 


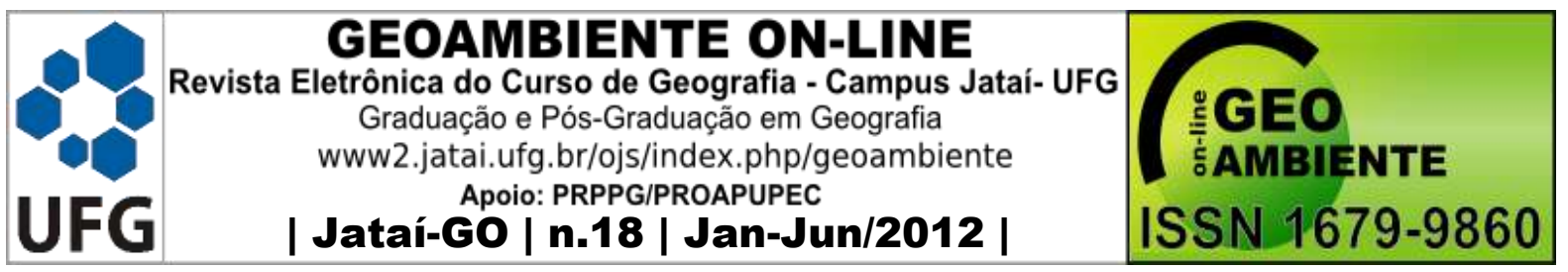

vida da comunidade local. Monitorando o movimento dos indivíduos entre casas, em diferentes vizinhanças em ruas diversas, tranquilas e agitadas foi possível comprovar,

[...] o nível de interação social entre vizinhos de uma determinada rua, ou o senso de comunidade naquela rua, era inversamente proporcional à sua quantidade de trânsito. O estudo aponta o tráfego como causa fundamental para a alienação do morador urbano, um efeito bem no centro do processo de dilapidação da cidadania contemporânea. (Rogers, 2008, p. 36)

Pensando desta maneira, nossa proposta contempla algumas poucas intervenções de grande monta e muitas de baixo custo visando que o entorno das praças centrais, como a Tubal Vilela e Sérgio Pacheco, sejam destinadas apenas à passagem do transporte público e ciclistas, bem como na criação de espaços de convivência para pedestres (Mapa 7).

Mapa 7 - Localização das praças Sérgio Pacheco e Tubal Vilela na área central de Uberlândia- MG

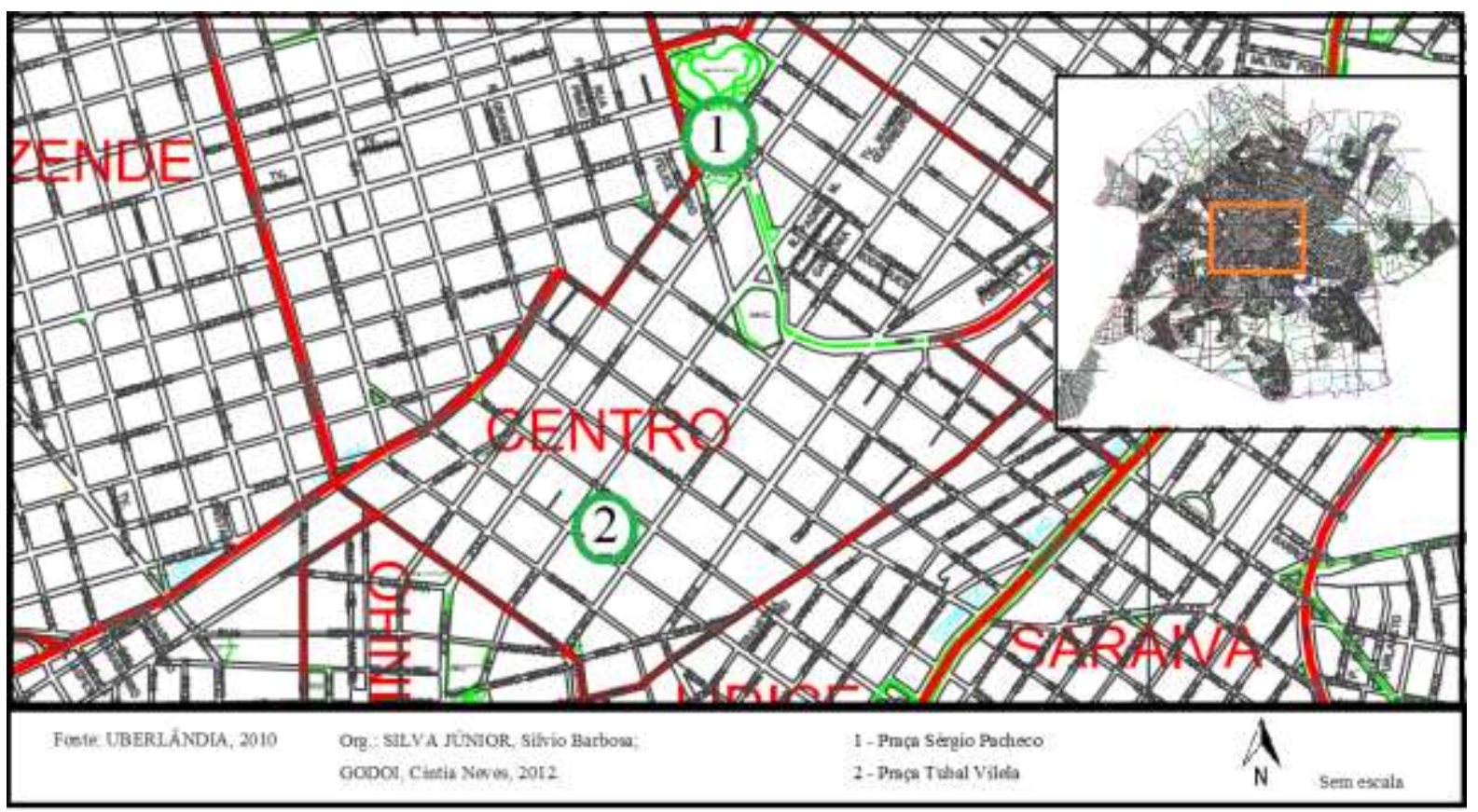

Além desta escolha, seguindo o exemplo de Dresden, poderia se determinar que em algumas das linhas, quando viável e exequível, a via permanente do bonde (Fotografia 03) corresse sobre gramado. Isto ocorrendo seja aproveitando o espaço dos canteiros para implantação da linha ou mesmo aproveitando uma faixa de tráfego, agregando áreas de recarga para ampliar a infiltração de água no solo. Considerando a execução da via 


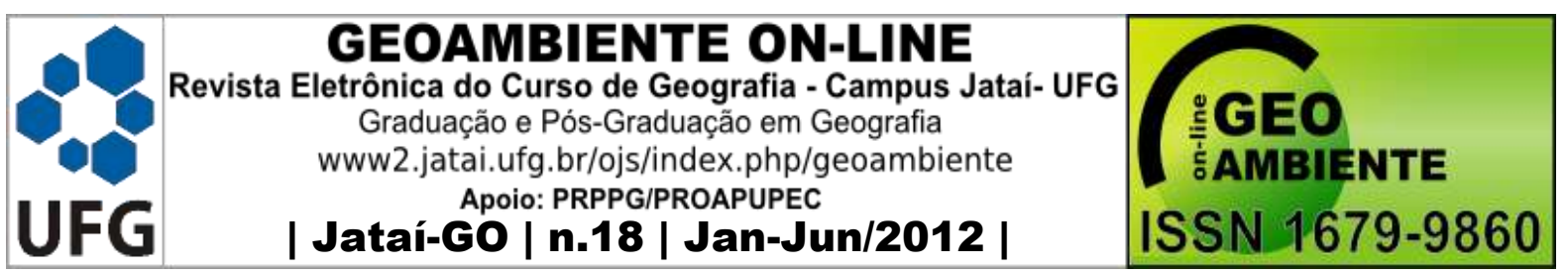

permanente em áreas que já sejam de domínio público, há de se esperar que sejam bem menos custosas do que no caso de serem executadas em áreas que necessitem de desapropriação prévia para sua execução.

Fotografia 03: Bonde correndo sobre gramado. Dresden, 2010.

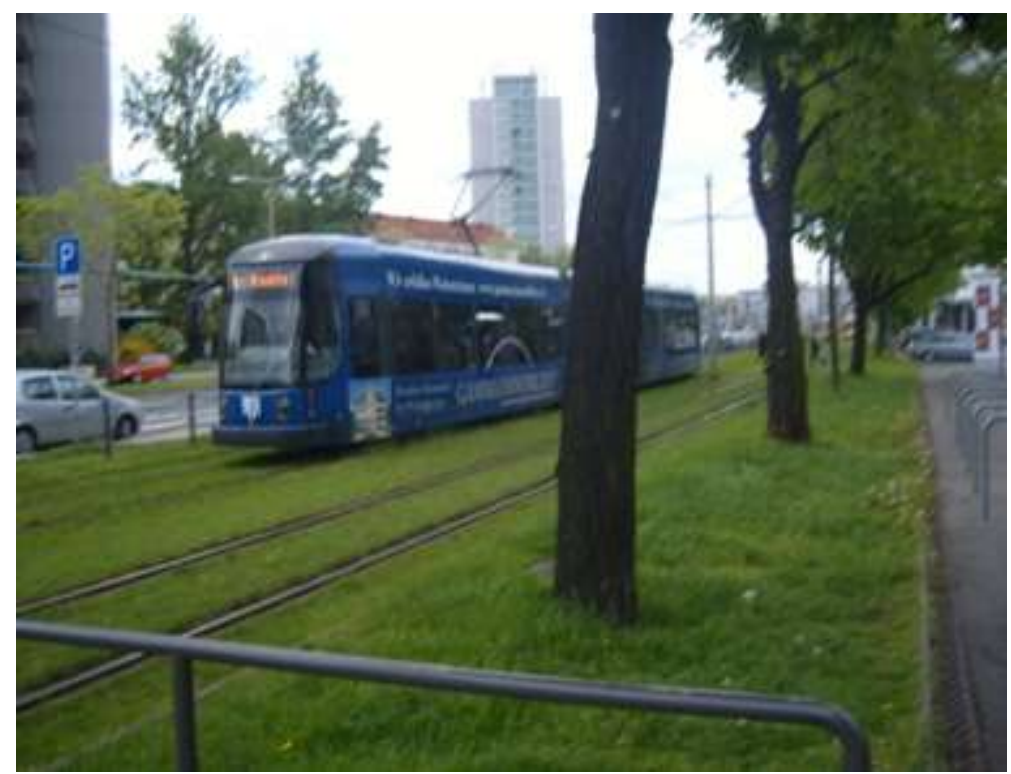

Autor: Silva Junior, 2010.

Fonte: Arquivo pessoal.

Esta proposta é baseada na necessidade de Uberlândia e diversas outras cidades no país e no mundo que sofrem com a impermeabilização do solo e tem suas infraestruturas destruídas de tempos em tempos por inundações ocasionadas justamente pelo modelo de gestão urbana que dissocia as intervenções urbanas dos aspectos do meio natural que hospeda a cidade.

El cresciente número de inundaciones catastróficas sufridas [...] pone de manifiesto la interacción entre la arquitetura y la agricultura. Los efectos de la expansión urbana, junto com la agricultura intensiva, han sobrepasado la capacidad del suelo de absorber preciptaciones excepcionales. El proyecto de edifícios y paisajes deve favorecer la absorción de las lluvias intensas para reducir la presión sobre los sistemas fluviales y de drenaje. Las superfícies duras deberían ser reemplazadas por otras que actúen como esponjas y puedan absorber la humedad para después liberarla gradualmente. (Edwards, 2005, p. 35) 


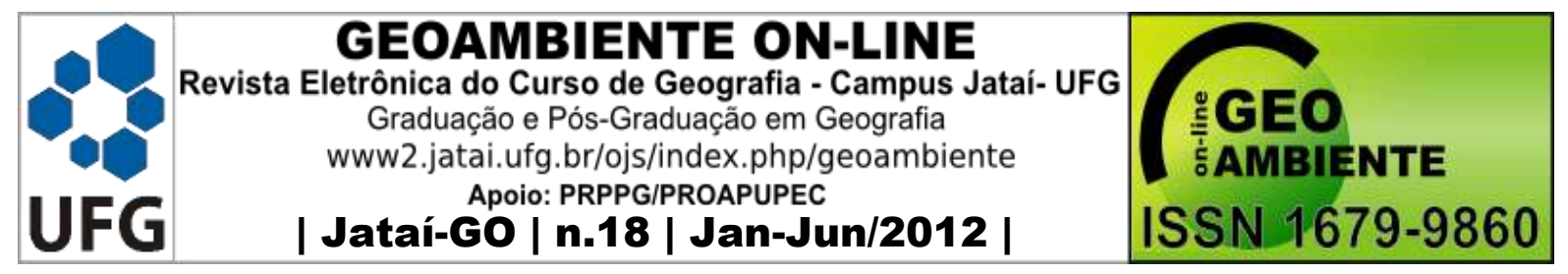

Em Uberlândia nos últimos anos houve diversas enchentes que arrasam os fundos de vales urbanizados em pouco tempo causando catástrofes. É importante que nos lembremos de que não é apenas nas áreas urbanas que o nível de recarga diminui crescentemente, as áreas que se destinam a atividades agrícolas também transformam os solos e o relevo causando dificuldade de infiltração e acelerando o trajeto da água e o curso dos rios.

Por fim, com o transporte de longa distância focado no transporte sobre trilhos, com as devidas segregações nas áreas de maior fluxo, e com uma operação séria do sistema e com informação amplamente difundida aos cidadãos/usuários, associado a medidas restritivas ao automóvel nas áreas centrais, haveria, como resultado um sistema de transportes mais confiável e com potencial de atrair passageiros dos modos individuais. Assim, um círculo virtuoso, no qual seria ampliado o número de usuários, proporcionando mais recursos para implantação da infraestrutura e melhoria constante do sistema, com redução de tarifa. Como externalidade positiva, a redução do tráfego nas vias principais da cidade e, por conseguinte, de todas as externalidades negativas a ele associada.

\section{6 - Considerações Finais}

Conhecer o caso das redes de transporte urbano de Dresden serviu para verificar o quanto problemas aparentemente complexos, envolvendo a questão da mobilidade urbana no Brasil, têm possibilidades de solução relativamente simples, desde que bem articuladas.

No elenco de problemas associados à mobilidade, observamos o predomínio dos modos individuais, notadamente o automóvel, enquanto os usuários dos transportes públicos e dos modos não-motorizados têm sua possibilidade de movimentação no espaço urbana prejudicados pela adaptação deste espaço ao uso do automóvel, bem como outras externalidades negativas geradas.

Focando nos usuários dos transportes públicos, em geral convivem com uma frota antiga e mal conservada - ao menos neste aspecto Uberlândia é bem servida -; com pouco conforto e pouca confiabilidade em relação aos horários. Falta regularidade pela idade e conservação da frota, bem como pelo fato de não haver segregação de corredores de ônibus de modo disseminado. Falta, além de regularidade, informação de qualidade, no sentido de orientar os usuários.

Uma rede sobre trilhos bem operada e bem concebida poderia superar estes problemas. Nos trilhos e com segregação adequada ao menos nas áreas de maior demanda, os 


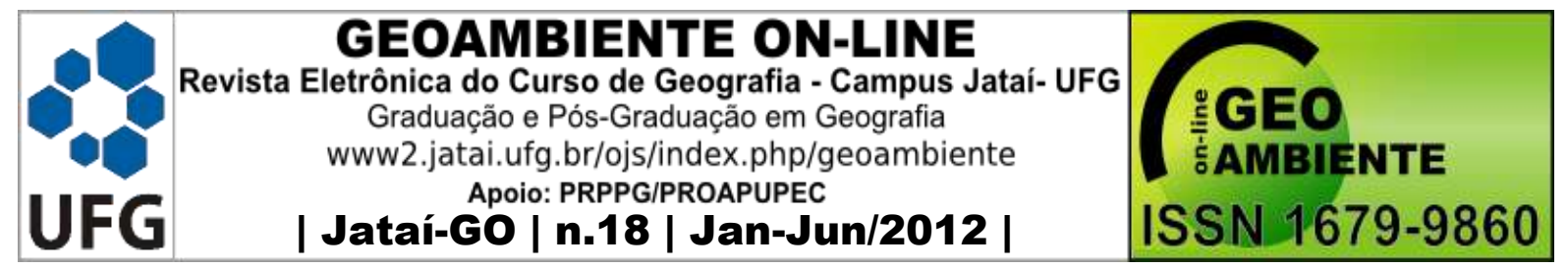

bondes não concorreriam com o restante dos veículos, não havendo perdas com o tráfego geral. Isto atenderia à questão da regularidade e confiabilidade do serviço. $\mathrm{O}$ transporte sobre trilhos, possuindo rota fixa, ao contrário do ônibus, oferece a oportunidade de adensamento ao redor do seu eixo, fixando a demanda onde há a oferta.

Um sistema confiável e presente próximo aos pontos onde o tráfego é gerado, acrescido de informação de qualidade sobre o sistema - mobiliário padronizado, painéis de informação, mapas - teria potencial de deslocamento de usuários do transporte individual para o coletivo, minorando o tráfego geral, bem como as externalidades negativas associadas e os custos de correção. Por fim, liberaria áreas para fluxos de pedestres e ciclistas, bem como para recreação e convívio e áreas verdes permeáveis, possibilitando menor escoamento superficial e maior infiltração.

Há de se ponderar, no entanto, a questão dos custos diferenciados entre, por exemplo, um sistema de BRT (Bus Rapid Transit, corredores segregados para ônibus) e Bondes (VLT - Veículo Leve sobre Trilhos, outro nome possível.). A literatura fala em um investimento até quatro vezes maior para o bonde em relação ao BRT (NTU, 2009); no entanto, casos recentes em que se debateu a implantação de um ou outro modo, revelaram uma diferença bem menor: 1,6 vezes no caso de Cuiabá (onde se optou pelo sistema de bondes) e 1,85 no Recife (onde se optou por BRT). Estes índices foram calculados com dados sobre mobilidade urbana do Portal da Transparência - Copa 2014. Há de se considerar que, para os custos do sistema de bondes, sempre estão incluídos os veículos, coisa que não acontece quando se pensa um sistema de BRT, em que os custos dos veículos costumam entrar na contabilidade do operador privado. Não se contabiliza, ainda, os custos e benefícios em relação ao controle do uso do solo e às emissões gasosas em ambos os casos, o que poderia mudar os índices apresentados.

Apesar de simples as medidas, a questão política é relevante. Não existe tradição de transporte sobre trilhos no Brasil, particularmente em áreas urbanas, e o lobby dos empresários do setor rodoviário é grande. A pressão deste grupo e, além disso, falta a mensuração de variáveis importantes como os custos e benefícios sobre o ordenamento do uso do solo e das emissões gasosas. Isto faz com que prevaleça a visão de que o custo de implantação de um sistema de bondes seja demasiado caro e inviável para demandas como as existentes nas cidades médias brasileiras. É preciso, neste sentido, que estudos procedam a 


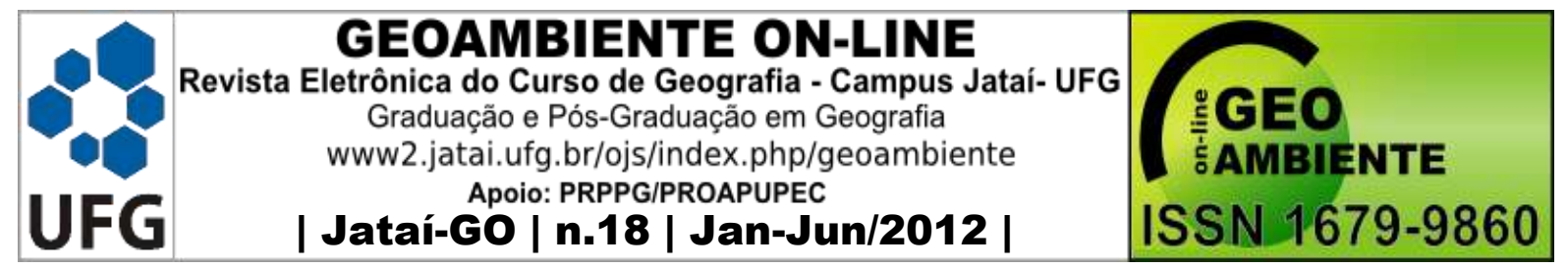

análises comparativas entre os sistemas operados por ônibus e aqueles por bondes, nos quais se mensure custo e cada benefício, visando desmistificar este discurso ora vigente.

\section{Referências}

CAIAFA, Janice. Aventura das Cidades: Ensaios e Etnografias. São Paulo: FGV, 2007.

CASTELLS, Manuel. La Questión Urbana. Madrid: Siglo Veitiuno Editores, 1974.

CENTRO DE INVESTIGACIONES PARA EL DESARROLLO. La autosostenibilidad de transporte público masivo Transmilenio em Bogotá. Bogotá: Universidad Nacional de Bogotá/ Facultad de Ciencias Econômicas/ Centro de Investigaciones para el Desarrollo, 2005.

CORRÊA, R. L. A Rede Urbana. São Paulo: Ática, 1989.

DRESDNER VERKEHRSBETRIEBE, disponível em: http://www.dvb.de/de/Startseite/, acessado em 18/07/2010

EDWARDS, B. Guia básica de la sustentabilidad. Ed. GG, 2005.

EMBRAPA MONITORAMENTO POR SATÉLITE, 2005. Disponível em: <http://www.urbanizacao.cnpm.embrapa.br>. Acesso em: 16 jun. 2009.

GONZALLES, Suely Franco Netto. A renda do solo urbano: hipóteses de explicação de seu papel na evolução da cidade. In: GONZALLES, Suely Franco Netto et al (org.) O Espaço da cidade: contribuição à análise urbana. São Paulo: Projeto, 1985.

GOTTDIENER, Mark. A produção Social do espaço Urbano. (trad. De Geraldo Gerson de Souza). São Paulo: EDUSP, 1993.

HARVEY, David. A Justiça Social e a Cidade. (trad. De Armando Corrêa da Silva). São Paulo: Hucitec, 1980.

RODITI, Itzhak. Dicionário Houaiss de Física. Rio de Janeiro: Editora Objetiva, 2005.

INSTITUTO BRASILEIRO DE GEOGRAFIA E ESTATÍSTICA. Contagem de População e Estimativas de População. Disponível em: 〈http://www.ibge.gov.br>

LEFEBVRE, Henry. O direito a cidade. (trad. Rubens Eduardo Frias. São Paulo: Centauro, 2001

LIPIETZ, Alain. Alguns Problemas da Produção Monopolista do espaço urbano. In: Espaço e debates: Revista de estudos Urbanos e Regionais. São Paulo: NERU, N 7, out/ dez, 1982.

LOJKINE, Jean. (trad. de Estela dos Santos Abreu). O estado capitalista e a quesão urbana. São Paulo: martins fontes, 1981. 


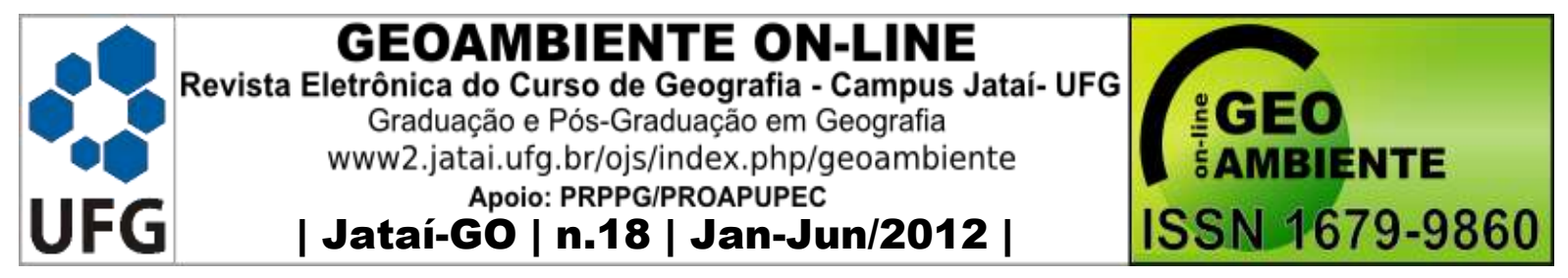

MIRANDA, E. E. de; GOMES, E. G. GUIMARÃES, M. Mapeamento e estimativa da área urbanizada do Brasil com base em imagens orbitais e modelos estatísticos. Campinas: Embrapa Monitoramento por Satélite, 2005. Disponível em: < http://www.urbanizacao.cnpm.embrapa.br>. Acesso em 10 de março de 2012.

MOURA, Rosa; KOKNIN, Thaís. Metropolização e governança urbana: relações transescalares em oposição a práticas municipalistas. In: GEOUSP - Espaço e Tempo; $\mathrm{n}^{\circ}$ 16; pp. 17-30. São Paulo; USP, 2004.

NTU - ASSOCIAÇÃO DE EMPRESAS DE TRANSPORTES URBANOS e JAIME LERNER ARQUITETOS ASSOCIADOS. Análise comparativa das modalidades de transporte público urbano. Curitiba: NTU, 2009.

OLIVEIRA JÚNIOR, João Alencar. Mobilidade Urbana Sustentável. Brasília: SEMOB/ Ministério das Cidades, 2009. ppt disponível em: <http://www.cntdespoluir.org.br/Downloads/Apresenta\%C3\%A7\%C3\%A3o\%20Jo\%C3\%A3 o\%20Alencar_SEMOB.pdf>; acesso em 12/06/2009.

PORTAL DA TRANSPARÊNCIA. Portal da Transparência Copa 2014. Disponível em <http://www.portaltransparencia.gov.br/copa2014/recife/mobilidade-urbana/> e <http://www.portaltransparencia.gov.br/copa2014/cuiaba/mobilidade-urbana/>; acesso em 10/03/2012.

ROGERS, R. Cidades para um pequeno planeta. Ed. GG, 2008.

SANTOS, Milton. A urbanização brasileira. São Paulo, Hucitec, 1993.

SANTOS, Milton; SILVEIRA, Maria Laura. O Brasil - Território e Sociedade no início de século XXI. Rio de Janeiro: Record, 2001.

SOBREIRA, Daniel Pessini. Subsídios para o estudo dos deslocamentos pendulares nas regiões metropolitanas paulistas: São Paulo, Campinas e Baixada Santista. $4^{\circ}$ Encontro Nacional sobre Migração. s.l. 200?. anais... Disponível em: <http://www.abep.nepo.unicamp.br/docs/anais/outros/4EncNacSobreMigracao/ST4-3.pdf>; acesso em: 10/06/2009.

UBERLÂNDIA. Lei Complementar $n^{\circ} 78$ de 27 de Abril de 1994 - Dispõe sobre o Plano Diretor do município de Uberlândia.

UBERLÂNDIA. Lei Complementar $n^{\circ} 432$, de 19 de outubro de 2006. Aprova o Plano Diretor do Município de Uberlândia, estabelece os princípios básicos e diretrizes para sua 


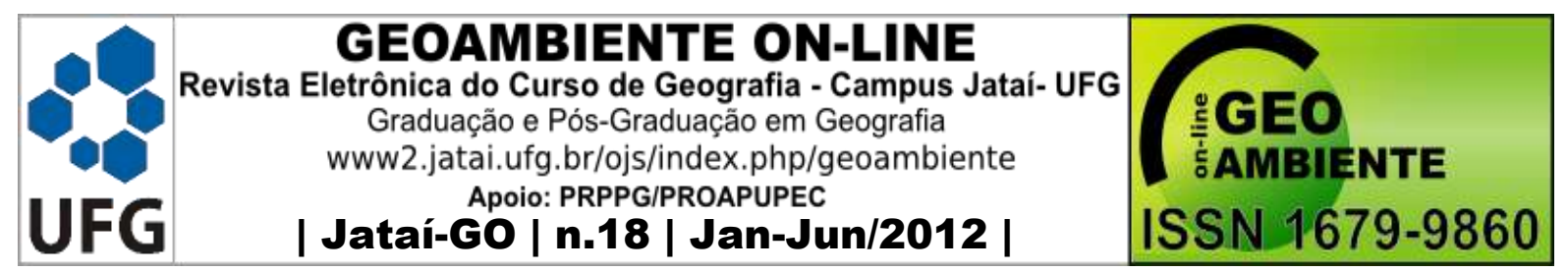

implantação, revoga a Lei Complementar $n^{\circ} 078$ de 27 de abril de 1994 e dá outras providências.

UBERLÂNDIA. Mapa $\quad$ base, $2010 . \quad$ Disponível em <http://www.uberlandia.mg.gov.br/uploads/cms_b_arquivos/1772.pdf>

UBERLÂNDIA. Planilha de custos do sistema de transporte coletivo urbano do município de Uberlândia. Uberlândia: Prefeitura Municipal, 2009

VASCONCELLOS, Eduardo de Alcântara. Transporte Urbano nos Países em Desenvolvimento. São Paulo: Unidas: Fapesp, 1996.

VILLAÇA, Flávio. Espaço intra-urbano no Brasil. São Paulo:Studio Nobel, 2001 